\title{
Grain Zinc and Iron Association Studies in Swarna X Type 3 RIL Population of Rice
}

\author{
D. Shivani $^{1^{*}}$, C. Cheralu ${ }^{2}$, C.N. Neeraja ${ }^{3}$ and V. Gouri Shankar ${ }^{4}$ \\ ${ }^{1}$ Department of Genetics and Plant Breeding, ${ }^{4}$ Department of Genetics and Plant Breeding, \\ College of Agriculture, PJTSAU, Rajendranagar, Hyderabad, India \\ ${ }^{2}$ Department of Genetics and Plant Breeding, PJTSAU, Rajendranagar, Hyderabad, India \\ ${ }^{3}$ Biotechnology Indian Institute of Rice Research, Rajendranagar, Hyderabad, India \\ *Corresponding author
}

\section{A B S T R A C T}

\begin{tabular}{|l|}
\hline Ke y w or d s \\
$\begin{array}{l}\text { Grain zinc and iron, } \\
\text { Rice, Yield } \\
\text { attributing traits }\end{array}$ \\
\hline Article Info \\
\hline $\begin{array}{l}\text { Accepted: } \\
\text { 07 April } 2018 \\
\text { Available Online: } \\
\text { 10 May } 2018\end{array}$ \\
\hline
\end{tabular}

The present study was undertaken with the objective to determine the degree of association between yield, yield attributing traits and grain Zinc and Iron concentration in Swarna x Type 3 RIL population of rice. $100 \mathrm{RIL}$ population were evaluated for identifying their efficiency with respect to ten characters. The correlation studies revealed that grain yield per plant showed strong positive significant association with plant height and 1000seed weight. Positive non- significant association of grain yield per plant was observed with days to 50 per cent flowering, panicle length, number of filled grains per panicle and significant negative correlation was observed for grain iron and zinc concentration.

\section{Introduction}

Rice is a staple food for millions of people and having great importance in food and nutritional security. Rice is the second most widely consumed cereal in the world next to wheat. From poorest to richest person in this world consume rice in one or other form. In the last two decades, new research findings generated by the nutritionists have brought to light the importance of micronutrients, vitamins and proteins in maintaining good health, adequate growth and even acceptable levels of cognitive ability apart from the problem of protein energy malnutrition. Biofortification is a genetic approach which aims at biological and genetic enrichment of food stuffs with vital nutrients (vitamins, minerals and proteins). Ideally, once rice is biofortified with vital nutrients, the farmer can grow indefinitely without any additional input to produce nutrient packed rice grains in a sustainable way. This is also the only feasible way of reaching the malnourished population 
in India. In this context breeders are now focusing on breeding for nutritional enhancement to overcome the problem of malnutrition.

The range of iron and zinc concentration in brown rice is $6.3-24.4 \mu \mathrm{g} / \mathrm{g}$ and $13.5-28.4 \mu \mathrm{g} / \mathrm{g}$ respectively. There is approximately a fourfold difference in iron and zinc concentration, suggesting some genetic potential to increase the concentration of these micronutrients in rice grains.

A scarce scientific literature is available on the association between grain iron and zinc content with grain yield. The present research was taken up to study the association of grain iron and zinc with grain yield.

\section{Materials and Methods}

The experiment was conducted at Indian Institute of Rice Research Farm, Ramachandrapuram, Hyderabad, India, during kharif, 2017. The experimental material comprised of 100 RILs of $F_{7}$ population derived from Swarna and Type 3 along with four checks (Swarna, Type 3, BPT 5204, Chittimutyalu) laid out in Augmented Block Design. All the recommended package of practices was followed along with necessary prophylactic plant protection measures to raise a good crop.

Five representative plants for each population were randomly selected to record observations on the quantitative characters under study. Data on days to $50 \%$ flowering (DFF) recorded at flowering stage while, plant height $(\mathrm{PH})$, panicle length (PL), number of productive tillers per plant (NPT) were recorded at harvest and panicle weight, number of filled grains per panicle (FGP), test-weight (TW), grain iron content $(\mathrm{Fe})$, grain zinc content $(\mathrm{Zn})$ and grain yield per plant (GY) were recorded after harvest. Grain
Iron and Zinc content were estimated by following recommended standard procedure i.e., X - Ray fluorescence Spectrometry (XRF).

\section{Statistical analysis}

Simple correlation coefficients were calculated for grain yield and its components using the formulae given by Webber and Moorthy (1952).

\section{Results and Discussion}

Grain yield is a complex character and is dependent on its contributing traits. The study was envisaged on character association, to assess the relationships among yield and its components and to have an insight into the causes for higher yield in hybrids and varieties. Simple correlations were worked out on yield and yield contributing characters in 100 RIL population of rice (Table 1).

\section{Days to $50 \%$ flowering}

The character days to 50 per cent flowering recorded a non-significant positive correlation with grain yield per plant (0.0807), test weight (0.1433), panicle weight (0.1232), number of filled grains per panicle (0.0690). It showed negative and significant correlation with plant height $(-0.2523 * *)$ and non-significant negative correlation for panicle length ($0.0135)$, number of productive tillers per plant $(-0.0674)$ and grain iron concentration ($0.0597)$ and grain zinc concentration ($0.1333)$. The Similar findings were recorded by Nandan et al., (2010), Sarker et al., (2014) for number of filled grains per panicle, Rao et al., (2014) for 1000 seed weight, Madhavilatha et al., (2005), Chandra et al., (2009), Nandan et al., (2010), Rao et al., (2014) for single plant yield, Rao et al., (2014) for panicle length and Ajmera et al., (2017) for grain iron and zinc concentration. 


\section{Plant height (cm)}

The trait plant height shown a significant positive correlation with single plant yield $(0.2150 *)$.

It had positive non-significant correlation with plant height (0.1145), number of productive tillers per plant (0.0901), panicle weight (0.0103), test weight (0.0233), negative significant correlation with grain iron concentration $(-0.2269 *)$, grain zinc concentration $\left(-0.1885^{*}\right)$, days to $50 \%$ flowering $(-0.2523 * *)$ and negative nonsignificant correlation with number of filled grains per panicle (-0.0247).

The results are in accordance with Rao et al., (2014) for number of productive tillers per plant, Nandan et al., (2010) for number of filled grains per panicle Sala and Geetha (2015) for panicle length, Dhurai et al., (2016) for 1000 seed weight, Rajendra Prasad et al., (2017) for panicle weight. Sala and Geetha (2015) for grain iron concentration, Nagesh $e t$ al., (2012) for grain zinc concentration Reddy et al., (2013), Patel et al., (2014), Biswash et al., (2015), Thippeswamy et al., (2016) and Priya et al., (2017) for single plant yield.

\section{Panicle length $(\mathrm{cm})$}

Panicle length registered non-significant positive correlation with plant height (0.1145), number of filled grains per panicle (0.0153), grain yield per plant (0.0306) and nonsignificant negative correlation with days to $50 \%$ flowering (-0.0135), 1000 grain weight (-0.0399), number of productive tillers per plant (-0.0059), panicle weight, (-0.0874) grain zinc concentration $(-0.1104)$ and grain iron concentration (0.0973).

Similar results were reported by Rao et al., (2014) for days to $50 \%$ flowering, Sala and Geetha (2015) for plant height, Rahman et al.,
(2014) for number of filled grains per panicle, Ajmera et al., (2017) for grain iron concentration, Nagesh et al., (2012) for grain zinc concentration Dhurai et al., (2016) for 1000 seed weight and number of productive tillers per plant, Madhavilatha et al., (2005), Seyoum et al., (2012) for single plant yield.

\section{Panicle weight}

Panicle weight exhibited significant positive correlation with 1000 grain weight $\left(0.2880^{* *}\right), \quad$ non-significant positive correlation with days to $50 \%$ flowering (0.1232), plant height $(0.1034)$, single plant yield (0.1099), non-significant negative correlation with plant height (-0.0874), number of productive tillers per plant ($0.0282)$, filled grains per panicle (-0.0229), grain iron concentration (-0.0909) and grain zinc concentration (-0.0183). Prasad et al., (2017) also reported similar results for 1000 seed weight and plant height.

\section{Number of productive tillers per plant}

Number of productive tillers per plant exhibited non-significant positive correlation with plant height (0.0901), grain yield per plant (0.0378).

It had negative non-significant correlation with days to $50 \%$ flowering $(-0.0674)$, panicle length (-0.0059), number of filled grains per panicle $(-0.0551)$, panicle weight $(-0.0282)$, test weight $(-0.0406)$, grain Iron concentration $(-0.0578)$ and grain Zinc concentration ($0.0705)$.

The results were in conformity with Rao et al., (2014) for plant height, Dhurai et al., (2016) for panicle length, Seyoum et al., (2012), Nikhil et al., (2014), Rahman et al., (2014) for single plant yield, Rao et al., (2014) for 1000 seed weight and Nagesh et al., (2012) for grain iron concentration. 
Table.1 Phenotypic correlation co-efficient for yield and yield attributes in RIL population of rice

\begin{tabular}{|c|c|c|c|c|c|c|c|c|c|c|}
\hline & DFF & PH & PL & NT & PW & FGP & TW & Fe & Zn & SPY \\
\hline DFF & 1.000 & $-0.2523^{* *}$ & -0.0135 & -0.0674 & 0.12325 & 0.0690 & 0.1433 & -0.0597 & -0.1333 & 0.0807 \\
\hline PH & & 1.000 & 0.1145 & 0.0901 & 0.10340 & -0.0247 & 0.0233 & $-0.2269^{*}$ & $-0.1885^{*}$ & $0.2150^{*}$ \\
\hline PL & & 1.0000 & -0.0059 & -0.08740 & 0.0153 & -0.0399 & -0.0007 & -0.1104 & 0.0306 \\
\hline NT & & & & 1.0000 & -0.02825 & -0.0551 & -0.0406 & -0.0578 & -0.0705 & 0.0378 \\
\hline PW & & & & 1.0000 & -0.0229 & $0.2888^{* *}$ & -0.0909 & -0.0183 & 0.1099 \\
\hline FGP & & & & & 1.000 & 0.0203 & $-0.1966^{*}$ & -0.0803 & 0.1027 \\
\hline TW & & & & & & 1.000 & -0.1286 & -0.0414 & $0.3937^{* *}$ \\
\hline Fe & & & & & & 1.000 & $0.6691^{* *}$ & $-0.4059^{* *}$ \\
\hline Zn & & & & & & & & 1.000 & $-0.4243^{* *}$ \\
\hline SPY & & & & & & & & & 1.000 \\
\hline
\end{tabular}

*Significant at $5 \%$ probability level

**Significant at $1 \%$ probability level

$\mathrm{DFF}=$ Days to $50 \%$ flowering $\quad \mathrm{PH}=$ Plant height $(\mathrm{cm})$

NT $=$ Number of tillers plant ${ }^{-1} \quad \mathrm{PW}=$ Panicle weight $(\mathrm{g})$

SPY $=$ Single plant yield $(\mathrm{g})$

$\mathrm{Zn}=\mathrm{Zinc}$

\section{Number of filled grains per panicle}

Number of filled grains per panicle exhibited a non-significant positive correlation with days to $50 \%$ flowering $(0.0690)$, panicle length (0.0153), grain yield per plant $(0.1027)$ and 1000 seed weight (0.0203) whereas significant negative correlation with grain iron concentration $\left(-0.1966^{*}\right)$ and nonsignificant negative correlation with plant height (-0.0247), number of productive tillers per plant (-0.0551), grain zinc concentration $(-0.0803)$ and panicle weight $(-0.0229)$.

Similar findings were reported by Nandan et al., (2010), Sarker et al., (2014) for days to 50 $\%$ flowering, Nandan et al., (2010) for plant height, Rahman et al., (2014) for panicle length, Biswash et al., (2015), Thippeswamy et al., (2016), Lakshmi et al., (2017) for 1000 seed weight, Rahman et al., (2014), Rashid et al., (2014) for single plant yield, Nagesh et al., (2012) for grain zinc concentration.
$\mathrm{PL}=$ Panicle length

FGP $=$ Filled grains per panicle

$\mathrm{Fe}=$ Iron

\section{0 grain weight}

Thousand grain weight showed highly significant positive correlation with panicle weight $\left(0.2888^{* *}\right)$, grain yield per plant $\left(0.3937^{* *}\right)$ and non-significant negative correlation with panicle length (-0.0399), number of productive tillers per plant ($0.0406)$, grain iron concentration $(-0.1288)$ and grain zinc concentration (-0.0414) and positive non-significant correlation with days to $50 \%$ flowering (0.1433), plant height (0.0233), number of filled grains per panicle (0.0203). Basavaraja et al., (2011), Chakraborty and Chaturvedi (2014), Naseem et al., (2014), Patel et al., (2014), Rahman et al., (2014), Rao et al., (2014), Rashid et al., (2014), Anil kumar et al., (2015), Ashok et al., (2016), Kalyan et al., (2017), Lakshmi et al., (2017), Priya et al., (2017) for grain yield per plant and Nagesh et al., (2013) for grain zinc and iron concentrations reported similar results 


\section{Grain zinc concentration}

Grain zinc concentration showed a negative significant correlation with grain yield per plant $(-0.4243 * *)$, and positive significant correlation with grain iron content $\left(0.6691^{* *}\right)$. The results were in accordance with Nagesh et al., (2013) for grain yield per plant and Gangashetty et al., (2013) and Nagesh et al., (2013) for grain iron concentration.

\section{Grain iron concentration}

Grain Iron concentration showed a negative significant correlation with grain yield per plant $\left(-0.4059^{* *}\right)$, significant positive correlation with grain zinc concentration $(0.6691 * *)$. Similar findings were reported by Nagesh et al., (2013) for grain yield per plant and Gangashetty et al., (2013) and Nagesh et al., (2013) for grain iron concentration.

\section{Grain yield per plant}

Grain yield per plant had significant positive association with plant height $(0.21500 *)$, 1000 seed weight $\left(0.3937^{* *}\right)$. The trait recorded a non- significant positive association with days to 50 per cent flowering (0.0807), panicle length (0.0306), number of productive tillers per plant (0.0378), panicle weight (0.1099), number of filled grains per panicle (0.1027) and showed significant negative correlation with grain iron concentration $\left(-0.4059^{* *}\right)$ and grain zinc concentration $\left(-0.4243^{* *}\right)$.

Similar kind of association was revealed by Madhavilatha et al., (2005), Rao et al., (2014) for days to $50 \%$ flowering, Patel et al., (2014), Biswash et al., (2015), Thippeswamy et al., (2016), Priya et al., (2017) for plant height, Seyoum et al., (2012), Rahman et al., (2014) for number of productive tillers per plant, Madhavilatha et al., (2005), Seyoum et al., (2012) for panicle length, Rahman et al., (2004) for number of filled grains per panicle, Patel et al., (2014), Anil Kumar et al., (2015), Ashok et al., (2016), Lakshmi et al., (2017) and Priya et al., (2017) for 1000 seed weight, Sala and Geetha (2015) for grain iron concentration.

The present study has revealed that grain yield had strong positive significant association with plant height and 1000-seed weight. Grain iron content and zinc content had no correlation with grain yield. Simultaneous selection / breeding can be taken up to enhance grain iron and zinc and grain yield because of absence of correlation.

\section{References}

Anil Kumar, Jabeen, F., Cheralu, C and Devi, R.G. 2015.Correlation and path analysis of yield and yield attributing characters of rice. BIOINFOLET 12 (2 B): 460 463.

Ashok, S., Jyothula, D.P and Babu, R. 2016. Character association and path analysis for yield components and grain quality parameters of rice (Oryza sativa L.). International Journal of Agricultural Science and Research.6 (6): 253-258.

Basavaraja, T., Gangaprasad, S and Dhusyantha Kumar, B.M. 2011. Correlation and path analysis of yield and yield attributes in local rice cultivars (Oryza sativa L.). Electronic Journal of plant breeding. 2(4): 523526.

Biswash, R., Zeba, N., Sharmin, M., Niaz, Md., Rahman, M.F., Farhat, F and Ahmed, M. 2015. Character association of T. aman rice (Oryza sativa L.) varieties of Bangladesh. AmericanEurasian Journal of Agricultural \& Environmental Sciences. 15 (3): 478484. 
Chakraborty, S and Chaturvedi, H.P. 2014. Genetic variability in upland rice (Oryza sativa L.) genotypes of Nagaland. Indian Research Journal of Genetics \& Biotechnology. 6(2): 374378.

Chandra, B.S., Reddy, T.D and Kumar, S.S. 2009 Variability parameters for yield, its components and quality traits in rice. Crop Research. 38 (1/3): 144-146.

Dhurai, S.Y., Bhati, P.K and Saroj, S.K. 2014.Studies on genetic variability for yield and quality characters in rice (Oryza sativa L.) under integrated fertilizer management. The Bioscan. 9(2): $845-848$.

Gangashetty, P., Salimath, P and Hanamaratti. N 2013. Genetic variability studies in genetically diverse non-basmati local aromatic genotypes in rice (Oryza sativa L.). Rice Genomics and Genetics.4 (2): 4-8.

Kalyan, B., Radha Krishna, K.V and Rao, L.V.S. 2017.Path coefficient analysis for yield and yield contributing traits in rice (Oryza sativa L.) genotypes.International Journal of Current Microbiology and Applied Sciences. 6(7): 2680-2687

Krishna, L., Raju, C.H.D and Raju, C.H.S. 2008. Genetic variability and correlation for yield and grain quality characters of rice germplasm. The Andhra Agricultural Journal. 55 (3): 276-279.

Lakshmi, L., Rao, B.M.N., Raju, S. Ch. and S. Reddy, N.S. 2017. Variability, correlation and path analysis in advanced generation of aromatic rice. International Journal of Current Microbiology and Applied Sciences. 6(7): 1798-1806.

Madhavilatha, L., Sekhar, M.R., Suneetha, Y and Srinivas, T. 2005. Genetic variability, correlation and path analysis for yield and quality traits in rice (Oryza sativa L.). Research on Crops. 6 (3): 527-537.

Nagesh, Babu, V.R., Rani. G.U., Reddy. T.D., Surekha, K and Reddy, D.V.V. 2013. Association of grain iron and zinc contents with yield in high yielding rice cultivars. Oryza. 50 (1): 41-44.

Naseem, I., Khan, A.S and Akhter, M. 2014. Correlation and path coefficient of some yield related traits in rice (Oryza sativa L.). International Journal of Scientific and Research Publications. 4 (4): 1-5.

Patel, J.R., Saiyad, M.R., Prajapati, K.N., Patel, R.A and Bhavani R.T. 2014. Genetic variability and character association studies in rainfed upland rice (Oryza sativa L.) Electronic Journal of Plant Breeding. 5(3): 531537.

Prasad, K.R., Krishna, K.R., Kumar, S.S., Senguttuvel, P and Rao, L.S. 2017. Character association and path analysis studies for quantitative traits in Hybrid Rice (Oryza sativa L.). International Journal of Pure and Applied Biosciences. 5(4): 1513-1518.

Priya, S.Ch, Suneetha, Y., Babu, R.D and Rao, S.V. 2017. Inter-relationship and path analysis for yield and quality characters in rice (Oryza sativa L.). International Journal of Science, Environment and Technology.6 (1): 381 $-390$.

Rahman, M.A., Hossain, M.S., Chowdhury, I.F., Matin, M.A and Mehraj, H. 2014. Variability study of advanced fine rice with correlation, path co-efficient analysis of yield and yield contributing characters. International Journal of Applied Science and Biotechnology.2 (3): 364-370.

Raju, C.H.S 2002. Study of genetic divergence, variability, stability, gene action and character association for certain physiological quality and yield components in rice (Oryza sativa L.) 
Ph.D Thesis, Acharya N.G. Ranga Agricultural University, Hyderabad.

Rao, V.T., Mohan, Y.C., Bhadru, D., Bharathi, D and Venkanna, V. 2014. Genetic variability and association analysis in rice.International Journal of Applied Biology and Pharmaceutical Technology. vol.5, issue 2.

Reddy, G.E., Suresh, B.G., Sravan, T and Reddy, P.A. 2013. Interrelationship and cause-effect analysis of rice genotypes in North East plain zone. The Bioscan. 8 (4): 1141-1144.

Sala, M., Ananda Kumar, C.R and Geetha, S. 2015. Variability studies for quality traits in rice with high iron and zinc content in segregating population. Journal of Cereals and Oilseeds. 6 (7): $39-42$.
Sarker, Md. M., Hassan, L., Islam, M.M., Rashid, Md. M and Seraj, S. 2014. Correlation and path coefficient analysis of some exotic early maturing rice (Oryza sativa L.) lines. Journal of Bioscience and Agriculture Research. 01 (01): 01-07.

Seyoum, M., Alamerew, S and Bantte, K. 2012. Genetic variability, heritability, correlation coefficient and path analysis for yield and yield related traits in upland rice (Oryza sativa L.). Journal of Plant Sciences. 7 (1): 13-22.

Thippeswamy, S., Mohan, C.Y., Srinivas, B. and Padmaja, D. 2016.Selection of diverse parental lines for heterotic hybrid development in rice (Oryza sativa L.) SABRAO Journal of Breeding and Genetics. 48 (3) 285-294.

\section{How to cite this article:}

Shivani, D., C. Cheralu, C.N. Neeraja and Gouri Shankar, V. 2018. Grain Zinc and Iron Association Studies in Swarna X Type 3 RIL Population of Rice. Int.J.Curr.Microbiol.App.Sci. 7(05): 708-714. doi: https://doi.org/10.20546/ijcmas.2018.705.085 